\title{
Burnout Syndrome and Associated Factors in Intensive Care Unit Nurses
}

\author{
Síndrome de Burnout e Fatores Associados em Enfermeiros de Unidade de Terapia Intensiva \\ Síndrome de Burnout y Factores Asociados en Enfermeros de Unidad de Terapia Intensiva
}

Núbia Samara Caribé de Aragão' ORCID: 0000-0002-2308-7474

Gabriella Bené Barbosa'

ORCID: 0000-0001-7183-0333

Cleide Lucilla Carneiro Santos' ORCID: 0000-0002-9894-3781

Deise dos Santos Silva Nascimento' ORCID: 0000-0002-0094-2618

Laís Barbosa Souza Vilas Bôas' ORCID: 0000-0003-3078-6393

Davi Félix Martins Júnior' ORCID: 0000-0002-7687-7373

Carlito Lopes Nascimento Sobrinho' ORCID: 0000-0002-6387-3760

'Universidade Estadual de Feira de Santana. Feira de Santana, Bahia, Brazil.

How to cite this article: Aragão NSC, Barbosa GBB, Santos CLC, Nascimento DSS, Vilas Bôas LBS, Martins Jr DF, et al. Burnout Syndrome and Associated Factors in Intensive Care Unit Nurses. Rev Bras Enferm. 2021;74(Suppl 3):e20190535. doi: http://dx.doi.org/10.1590/0034-7167-2019-0535

Corresponding author: Núbia Samara Caribé de Aragão E-mail: nscaribe@hotmail.com

EDITOR IN CHIEF: Dulce Barbosa ASSOCIATE EDITOR: Marcia Magro

Submission: 12-13-2019

Approval: 09-13-2020

\section{ABSTRACT}

Objective: to estimate prevalence and factors associated with Burnout Syndrome in intensive care nurses in a city in the state of Bahia. Methods: a cross-sectional, population-based study carried out with 65 intensive care nurses through a self-administered questionnaire, from July to November 2016, containing sociodemographic data, lifestyle, work characteristics. To define burnout syndrome, the Maslach Burnout Inventory was used. Results: Burnout Syndrome prevalence was $53.6 \%$, an association was observed with age, tobacco consumption, alcohol use, weekly night shift hours, employment relationship, having an intensive care specialist title, number of patients on duty, monthly income and considering active or high-strain job. Conclusion: the results of this study can contribute to expanding the discussion on stressful working conditions in Intensive Care Units.

Descriptors: Nurses; Burnout, Professional; Intensive Care Units; Occupational Health; Cross-Sectional Studies.

\section{RESUMO}

Objetivo: estimar a prevalência e os fatores associados à Síndrome de Burnout em enfermeiros intensivistas de uma cidade do estado da Bahia. Métodos: estudo transversal, populacional, realizado com 65 enfermeiros intensivistas por meio de um questionário autoaplicável no período de julho a novembro de 2016, contendo dados sociodemográficos, hábitos de vida, características do trabalho. Para definir a Síndrome de Burnout, utilizou-se o Maslach Burnout Inventory. Resultados: a prevalência da Síndrome de Burnout foi de 53,6\%. Observou-se associação com a idade, consumo de tabaco, uso bebida alcoólica, carga horária semanal de plantão noturno, vínculo de trabalho, possuir título de especialista em terapia intensiva, número de pacientes assistidos por plantão, renda mensal e considerar o trabalho ativo ou de alta exigência. Conclusão: os resultados deste estudo podem contribuir para a ampliação da discussão sobre as condições estressantes de trabalho no ambiente de Unidade de Terapia Intensiva.

Descritores: Enfermeiras e Enfermeiros; Esgotamento Profissional; Unidade de Terapia Intensiva; Saúde do Trabalhador; Estudos Transversais.

\section{RESUMEN}

Objetivo: estimar la prevalencia y factores asociados al Síndrome de Burnout en enfermeras de cuidados intensivos de una ciudad del estado de Bahía. Métodos: estudio poblacional, transversal, realizado con 65 enfermeros de cuidados intensivos mediante cuestionario autoadministrado de julio a noviembre de 2016, que contiene datos sociodemográficos, estilo de vida, características laborales. Para definir el Síndrome de Burnout se utilizó el Inventario de Burnout de Maslach. Resultados: la prevalencia del Síndrome de Burnout fue de $53,6 \%$. Hubo asociación con la edad, el consumo de tabaco, el consumo de bebidas alcohólicas, las horas semanales en el turno de noche, la relación laboral, tener un título de especialista en cuidados intensivos, número de pacientes atendidos de guardia, ingreso mensual y considerar trabajo activo o exigente. Conclusión: los resultados de este estudio pueden contribuir a ampliar la discusión sobre las condiciones laborales estresantes en el entorno de la Unidad de Cuidados Intensivos.

Descriptores: Enfermeras y Enfermeros; Agotamiento Profesional; Unidades de Cuidados Intensivos; Salud Laboral; Estudios Transversales. 


\section{INTRODUCTION}

Burnout Syndrome (BS) is defined as a psychological syndrome caused by the body's reaction to chronic stress related to work, in people who have direct and prolonged contact with other human beings, such as Intensive Care Unit (ICU) workers ${ }^{(1)}$. The term burnout is defined, according to English jargon, as that which ceased to function due to an absolute lack of energy, i.e., that or that which reached its limit, with impairment of its physical or mental performance ${ }^{(1-2)}$.

$\mathrm{BS}$ is a condition characterized by emotional exhaustion, depersonalization, and inefficiency ${ }^{(3-4)}$. Emotional exhaustion refers to depletion of an individual's emotional resources, and, in general, is due to overload and conflict in interpersonal relationships, depersonalization is characterized by professionals' emotional instability, who starts to relate to patients and colleagues in a cold and impersonal way, ineffectiveness, in turn, is related to the feeling of incompetence and negative self-assessment, related to dissatisfaction and unhappiness with work ${ }^{(3-4)}$.

ICU is intended for continuous and intensive care for critically ill patients. It has state-of-the-art technology and has professionals who deal with complex, emergency situations on a daily basis and which require strong emotional balance. These characteristics work as stressors, significantly influencing the health and quality of life of professionals working in this environment ${ }^{(1-5)}$.

Intensive care is a particularly stressful specialty for several reasons, such as living with critically ill patients and with death, daily. The job requires qualified technical knowledge, specific skills, high concentration, quick thinking and emotional control to deal with issues related to patients and their families, in addition to a need for continuous scientific updating considering the technical-scientific development that the specialty has been presenting throughout of the last few years ${ }^{(1)}$. All of this can overload professionals and increase their vulnerability to burnout development ${ }^{(1,5)}$ in intensive care nurses, who are daily subjected to stressful situations, resulting from numerous factors they are exposed to in the ICU environment.

\section{OBJECTIVE}

To estimate prevalence and factors associated with Burnout Syndrome in intensive care nurses in a city in the state of Bahia.

\section{METHODS}

\section{Ethical aspects}

This study was approved by the Research Ethics Committee of Universidade Estadual de Feira de Santana (REC-UEFS), in 2015, meeting all the determinations of Resolution 466 of the Brazilian National Health Council (Conselho Nacional de Saúde), which regulates research involving human beings in $\mathrm{Brazi}^{(6)}$.

\section{Design, period and place of study}

This is an observational, cross-sectional study, guided by the STROBE tool, exploratory and population. All nurses who worked in intensive care at seven public and private hospitals with Intensive Care Units in the city of Feira de Santana, Bahia, were studied. Data were collected from July to November 2016 through a questionnaire.

\section{Population or sample}

Of the eighty-five (85) nurses initially eligible, five (05) were not found during data collection and fifteen (15) refused to participate in the study, constituting a population of 65 workers, representing $80 \%$ of the initially eligible population. Of these workers, $41.5 \%$ (27) work in an adult ICU, 51.0\% (33) in a pediatric or neonatal ICU and $7.5 \%$ (5) did not respond.

All nurses working in intensive care who consented to participate in the study were considered eligible after reading and signing the Informed Consent Form (ICF). The inclusion criteria were: working at ICU for at least six (06) months, to avoid the bias of a healthy worker. The exclusion criteria were: being on vacation, sick leave and premium and being in administrative activities.

\section{Study protocol}

In data collection, a structured and validated instrument was used, consisting of seven blocks of questions about: the sociodemographic profile; general information about ICU work; workplace; psychosocial aspects of work, using the Job Content Questionnaire (JCQ); lifestyle and mental health of workers, using the Maslach Burnout Inventory (MBI) to identify BS.

The self-administered questionnaire, the ICF and a letter of presentation with justification of the work were delivered to each professional in the units, by the researchers, marking the location and time of the return with workers. Professionals who did not return the questionnaire on the scheduled date were contacted by phone, seeking to minimize losses. The questionnaires were returned in sealed envelopes, to guarantee confidentiality and confidentiality.

The Job Content Questionnaire is a questionnaire with 31 control questions (09); Demand (13) and Social Support (09), analyzing the dimensions of control over work, psychological demand and how the combination of these dimensions identifies contexts of risks to workers' health. Questions are measured on a scale of 1 to 4 ( $1=$ strongly disagree; $2=$ disagree; $3=$ agree; $4=$ strongly agree) ${ }^{(7)}$. The psychological demand considers the importance of the activity on workers in relation to time control for carrying out activities related to existing social conflicts ${ }^{(7)}$. The control over work activity is related to the workers' ability to perform the tasks assigned to them and the opportunity to collaborate in decisions in the workplace ${ }^{(7)}$.

Using the JCQ questionnaire allows building quadrants organized according to the combination of information related to psychological demand and activity control at work, with a combination of low strain and high control being considered as low demands. Passive work corresponds to low demand and low control and active work represents high demand and high control and high strain, high demand and low control $\left.\right|^{(7)}$. In order to build the demand and control indicators, the sum of the variables related to each of these indicators was performed, observing the weightings provided for in the model. For dichotomization of demand (low/high) and control (low/high), the median was defined as cutoff point. 
BS was measured using $\mathrm{MBI}$, an instrument composed of 22 questions about feelings and attitudes that encompass three fundamental dimensions of the syndrome, emotional exhaustion (9 statements), depersonalization (5 statements) and personal fulfillment (8 statements), divided into three scales seven points ranging from 0 to $6^{(8-9)}$.

Thus, the dimensions that characterize BS were described independently, using cut-off points, considering, for emotional exhaustion, high level of BS ( $\geq 27$ points), moderate level of BS (between 17 to 26 points) and low level of BS (<16 points); for depersonalization, high level ( $\geq 13$ points), moderate level (between 7 to 12 points) and low level ( $<6$ points). The score related to personal achievement goes in the opposite direction to the others, for high level (between 0 to 31 points), moderate level (from 32 to 38 points) and low level ( $\geq 39$ points) ${ }^{(8-9)}$.

There is still no consensus in the scientific literature for BS classification. In this regard, Grunfeld et al. $(2000)^{(10)}$ classify the syndrome by the presence of a high level in one of the three dimensions of $\mathrm{MBI}$, such as exhaustion, depersonalization, and personal fulfillment. This study adopted the criterion Grunfeld et al. $(2000)^{(10)}$, for BS classification.

A pilot study was carried out in a pediatric emergency unit in the city, aiming at verifying the approximate time of completion and clarity of the data collection instrument, with 6 professionals (two physicians, two nurses and two physical therapists). The suggestions were incorporated, having generated some modifications in the original instrument. The work was published in all hospitals that had intensive care units in the city.

\section{Analysis of results, and statistics}

In order to minimize typing errors and guarantee the quality control of the typed data, double typing was performed using the EpiData for Windows program, version 3.1. After this procedure, data were exported to the Statistical Package for Social Sciences (SPSS) 9.0 program, for statistical analysis.

Descriptive data analysis was performed by calculating the absolute and relative frequency of categorical variables and measures of central tendency and dispersion of numerical variables. Association analysis was performed between independent variables: age group, sex, on-duty activity, weekly on-duty workload, weekly workload in activities that generate income, monthly income, form of insertion in the labor market (salaried public sector or others), demand (JCQ), control (JCQ) and its quadrants with the result of $\mathrm{MBI}$ (presence and absence of burnout), adopted as a dependent variable Prevalence Ratio (PR) was used to measure the association between the variables studied, and the Confidence Interval $(\mathrm{Cl})$, with a $95 \%$ significance level $(\mathrm{Cl}-95 \%)$, was used to measure statistical significance ${ }^{(11)}$. Data were presented in tables.

\section{RESULTS}

Among the nurses studied, there was a predominance of females $90.8 \%$. It is maintained that nursing is a predominantly female profession ${ }^{(1,12)}$. The average age found was 33.9 years, with a standard deviation of \pm 6.3 and minimum and maximum values in 21 and 52, respectively. With regard to marital status, the majority, $57.0 \%$, reported having a partner. Regarding the number of children, $54.0 \%$ reported not having children. With regard to lifestyle, $4.6 \%$ reported using tobacco and $50.8 \%$ reported using alcohol. As for physical activity, 53.8\% practiced it.

Table 1 - Sociodemographic characteristics, lifestyle and factors related to the work of intensive care nurses in a large city in Bahia, Brazil, 2016

\begin{tabular}{|c|c|c|}
\hline Personal and functional characteristics & $n^{*}$ & $\%$ \\
\hline $\begin{array}{l}\text { Sex } \\
\quad \text { Female } \\
\text { Male }\end{array}$ & $\begin{array}{l}65 \\
59 \\
06\end{array}$ & $\begin{array}{c}100.0 \\
90.8 \\
9.2\end{array}$ \\
\hline $\begin{array}{l}\text { Age } \\
\leq 34 \text { years old } \\
>34 \text { years old }\end{array}$ & $\begin{array}{l}62 \\
39 \\
23\end{array}$ & $\begin{array}{r}100.0 \\
62.9 \\
37.1\end{array}$ \\
\hline $\begin{array}{l}\text { Marital status } \\
\text { With companion } \\
\text { No companion }\end{array}$ & $\begin{array}{l}63 \\
36 \\
27\end{array}$ & $\begin{array}{r}100.0 \\
57.1 \\
42.9\end{array}$ \\
\hline $\begin{array}{l}\text { Children } \\
\text { Yes } \\
\text { No }\end{array}$ & $\begin{array}{l}63 \\
29 \\
34\end{array}$ & $\begin{array}{l}100.0 \\
46.0 \\
54.0\end{array}$ \\
\hline $\begin{array}{l}\text { Smoking } \\
\text { Yes } \\
\text { No }\end{array}$ & $\begin{array}{l}64 \\
03 \\
61\end{array}$ & $\begin{array}{c}100.0 \\
4.6 \\
95.3\end{array}$ \\
\hline $\begin{array}{l}\text { Alcoholism } \\
\text { Yes } \\
\text { No }\end{array}$ & $\begin{array}{l}65 \\
33 \\
32\end{array}$ & $\begin{array}{r}100.0 \\
50.8 \\
49.2\end{array}$ \\
\hline $\begin{array}{l}\text { Physical activity } \\
\text { Yes } \\
\text { No }\end{array}$ & $\begin{array}{l}65 \\
35 \\
30\end{array}$ & $\begin{array}{r}100.0 \\
53.8 \\
46.2\end{array}$ \\
\hline $\begin{array}{l}\text { Employment relationship } \\
\text { Public employee } \\
\text { Others (temporary contracts) }\end{array}$ & $\begin{array}{l}64 \\
18 \\
46\end{array}$ & $\begin{array}{r}100.0 \\
28.0 \\
72.0\end{array}$ \\
\hline $\begin{array}{l}\text { Night shift } \\
\leq 24 \text { hours } \\
>24 \text { hours }\end{array}$ & $\begin{array}{l}47 \\
31 \\
16\end{array}$ & $\begin{array}{r}100.0 \\
66.0 \\
34.0\end{array}$ \\
\hline $\begin{array}{l}\text { Weekly working hours** } \\
\quad \leq 54 \text { hours } \\
>54 \text { hours }\end{array}$ & $\begin{array}{l}61 \\
31 \\
30\end{array}$ & $\begin{array}{r}100.0 \\
50.8 \\
49.2\end{array}$ \\
\hline $\begin{array}{l}\text { Other work } \\
\text { Yes } \\
\text { No }\end{array}$ & $\begin{array}{l}63 \\
40 \\
23\end{array}$ & $\begin{array}{r}100.0 \\
63.5 \\
36.5\end{array}$ \\
\hline $\begin{array}{l}\text { ICU specialist } \\
\text { Yes } \\
\text { No }\end{array}$ & $\begin{array}{l}56 \\
37 \\
19\end{array}$ & $\begin{array}{r}100.0 \\
66.0 \\
34.0\end{array}$ \\
\hline $\begin{array}{l}\text { Working time in ICU (years) } \\
\leq 6 \text { years } \\
>7 \text { years }\end{array}$ & $\begin{array}{l}61 \\
35 \\
26\end{array}$ & $\begin{array}{r}100.0 \\
57.4 \\
42.6\end{array}$ \\
\hline $\begin{array}{l}\text { Work sector } \\
\quad \text { Adult ICU } \\
\text { Pediatric and neonatal ICU }\end{array}$ & $\begin{array}{l}60 \\
27 \\
33\end{array}$ & $\begin{array}{r}100.0 \\
41.5 \\
51.0\end{array}$ \\
\hline $\begin{array}{l}\text { Patients under their responsibility } \\
\leq 10 \text { patients } \\
>10 \text { patients }\end{array}$ & $\begin{array}{l}63 \\
28 \\
35\end{array}$ & $\begin{array}{r}100.0 \\
44.4 \\
55.6\end{array}$ \\
\hline $\begin{array}{l}\text { Income }{ }^{* *} \\
\text { Below } 3,000.00 \text { to } 6,000.00 \\
6,001 \text { to } 20,000.00\end{array}$ & $\begin{array}{l}63 \\
49 \\
14\end{array}$ & $\begin{array}{r}100.0 \\
77.8 \\
22.2\end{array}$ \\
\hline
\end{tabular}

As for professional characteristics, the predominant type of employment contract was the hired worker (contract according to Consolidation of Labor Laws - CLT) combined with other types of temporary contracts, accounting for $72 \%$ of the nurses studied, corroborating the precariousness in the employment contracts, 
situation often found today ${ }^{(13)}$. The contract as an employee in the public sector was informed by $28.0 \%$ of nurses. It was also observed that the majority, $64.0 \%$, had another job. The average monthly net income varied between 3 and 6 minimum wages to $77.8 \%$, and $22.2 \%$ reported an income higher than 6 minimum wages.

Among the workers studied, $66.0 \%$ had the title of specialist in intensive care. With regard to working time in ICU, $57.4 \%$ had a service time less than or equal to 6 years and $42.6 \%$ more than 7 years. Concerning workday, $49.2 \%$ reported working more than 54 hours a week in activities that generate income. With regard to work shift, $66.0 \%$ reported working at night shift for at least 24 hours a week. It was also observed that the majority of professionals $66.5 \%$ worked elsewhere and that, in ICU, most $53.8 \%$ cared for 10 patients or more (Table 1 ).

Table 2 - Frequency of dimensions and Burnout Syndrome prevalence measured by the Maslach Burnout Inventory in intensive care nurses in a large city in Bahia, Brazil, 2016

\begin{tabular}{lcc}
\hline Dimensions & $\mathbf{n}^{*}$ & $\%$ \\
\hline Emotional exhaustion & 61 & 100 \\
Low & 19 & 31.0 \\
Moderate & 17 & 28.0 \\
High & 25 & 41.0 \\
Depersonalization & 62 & 100 \\
Low & 39 & 63.0 \\
Moderate & 19 & 30.5 \\
High & 04 & 6.5 \\
Ineffectiveness & 60 & 100 \\
High & 10 & 17.0 \\
Moderate & 15 & 25.0 \\
Low & 35 & 58.0 \\
Burnout Syndrome ${ }^{* *}$ & 56 & 100 \\
Yes & 30 & 53.6 \\
No & 26 & 44.4 \\
\hline
\end{tabular}

Note: *Valid answers, excluding those ignored; **Burnout Syndrome, classified by the high level in one of Maslach Burnout Inventory dimensions.

Table 3 - Prevalence Ratio and 95\% Confidence Interval for the association between sociodemographic variables, lifestyle and Burnout Syndrome in intensive care nurses in a large city in Bahia, Brazil, 2016

\begin{tabular}{|c|c|c|c|c|}
\hline \multirow[t]{2}{*}{ Variables } & \multicolumn{4}{|c|}{$\begin{array}{l}\text { Nurses suspected with Burnout } \\
\text { Syndrome }\end{array}$} \\
\hline & $\mathbf{n}^{*}$ & Prevalence \% & PR & $\mathrm{Cl}$ \\
\hline Age & & & & \\
\hline $\begin{array}{l}\leq 34 \text { years } \\
>34 \text { years }\end{array}$ & $\begin{array}{l}24 \\
10\end{array}$ & $\begin{array}{l}63.2 \\
45.5\end{array}$ & 1.37 & $0.82-----2.33$ \\
\hline Marital status & & & & \\
\hline $\begin{array}{l}\text { With companion } \\
\text { No companion }\end{array}$ & $\begin{array}{l}20 \\
14\end{array}$ & $\begin{array}{l}57.1 \\
53.8\end{array}$ & 1.06 & 0.61-----1.89 \\
\hline $\begin{array}{l}\text { Children } \\
\text { No } \\
\text { Yes }\end{array}$ & $\begin{array}{l}19 \\
15\end{array}$ & $\begin{array}{l}57.6 \\
53.6\end{array}$ & 1.07 & 0.68-----1.69 \\
\hline $\begin{array}{c}\text { Smoking } \\
\text { Others } \\
\text { Never }\end{array}$ & $\begin{array}{l}03 \\
32\end{array}$ & $\begin{array}{l}100 \\
54.2\end{array}$ & 1.84 & $1.46-----2.33^{* *}$ \\
\hline $\begin{array}{l}\text { Alcoholism } \\
\text { Yes } \\
\text { No }\end{array}$ & $\begin{array}{l}21 \\
14\end{array}$ & $\begin{array}{l}65.6 \\
45.2\end{array}$ & 1.45 & $1.43----1.79^{* *}$ \\
\hline $\begin{array}{l}\text { Physical activity } \\
\text { Yes } \\
\text { No }\end{array}$ & $\begin{array}{l}14 \\
21\end{array}$ & $\begin{array}{l}48.3 \\
61.8\end{array}$ & 0.78 & 0.49-----1.24 \\
\hline
\end{tabular}

Table 2 shows the frequency of the dimensions and burnout prevalence, assessed using MBI. Burnout was classified by the high level in at least one dimension of MBI. There was a prevalence of $53.6 \%$ of BS among intensive care nurses. When the dimensions were analyzed separately, it was found that $41.0 \%$ had a high level of emotional exhaustion, $6.5 \%$ depersonalization and $17.0 \%$ revealed a low level of personal fulfillment. The frequency of the moderate level of depersonalization was high, 30.5\%.

Table 3 presents $\mathrm{PR}$ and $\mathrm{Cl}$ for association between sociodemographic variables, lifestyle and BS in intensive care nurses. The results found revealed a prevalence of $63.2 \%$ in professionals aged 34 years or less $(P R=1.37)$, a result that did not present statistical significance. Nurses who reported having a partner had a prevalence of $57.1 \%(P R=1.06)$. Those who reported not having children had a prevalence of $57.6 \%(P R=1.07)$. Those who reported using tobacco and using alcohol had a prevalence of $100 \%$ ( $P R=1.84)$, and $65.6 \%$ ( $P R=1.45)$, respectively, statistically significant results. Performing physical activity had the lowest prevalence, $48.3 \%(P R=0.78)$, a result that did not present statistical significance.

Table 4 - Prevalence Ratio and 95\% Confidence Interval for association between work-related variables and Burnout Syndrome in intensive care nurses from a large city in Bahia, Brazil, 2016

\begin{tabular}{|c|c|c|c|c|}
\hline \multirow[t]{2}{*}{ Variables } & \multicolumn{4}{|c|}{$\begin{array}{l}\text { Nurses suspected with Burnout } \\
\text { Syndrome }\end{array}$} \\
\hline & $n^{*}$ & Prevalence \% & PR & $\mathbf{C l}$ \\
\hline Employment relationship & & & & \\
\hline $\begin{array}{l}\text { Public employee } \\
\text { Others }\end{array}$ & $\begin{array}{l}12 \\
23\end{array}$ & $\begin{array}{l}66.7 \\
52.3\end{array}$ & 1.28 & 0.83-----1.96 \\
\hline $\begin{array}{l}\text { Night shift** } \\
\leq 24 \text { hours } \\
>24 \text { hours }\end{array}$ & $\begin{array}{l}26 \\
07\end{array}$ & $\begin{array}{l}65.0 \\
46.7\end{array}$ & 1.39 & $0.76-----2.50$ \\
\hline $\begin{array}{l}\text { Working hours** } \\
\quad \geq 36 \text { hours } \\
<36 \text { hours }\end{array}$ & $\begin{array}{l}08 \\
27\end{array}$ & $\begin{array}{l}61.5 \\
57.4\end{array}$ & 1.07 & $0.65----1.76$ \\
\hline $\begin{array}{l}\text { Other work } \\
\text { No } \\
\text { Yes }\end{array}$ & $\begin{array}{l}25 \\
10\end{array}$ & $\begin{array}{l}65.8 \\
43.5\end{array}$ & 1.51 & $0.90-----2.54$ \\
\hline $\begin{array}{l}\text { ICU specialist } \\
\text { Yes } \\
\text { No }\end{array}$ & $\begin{array}{l}33 \\
01\end{array}$ & $\begin{array}{l}58.9 \\
25.0\end{array}$ & 2.36 & 0.43-----13.0 \\
\hline $\begin{array}{l}\text { Working time in ICU } \\
>7 \text { years } \\
\leq 6 \text { years }\end{array}$ & $\begin{array}{l}15 \\
20\end{array}$ & $\begin{array}{l}57.7 \\
57.1\end{array}$ & 1.01 & $0.65----1.56$ \\
\hline $\begin{array}{l}\text { Work sector } \\
\text { Adult ICU } \\
\text { Pediatric and neonatal ICU }\end{array}$ & $\begin{array}{l}18 \\
16\end{array}$ & $\begin{array}{l}66.7 \\
53.3\end{array}$ & 1.25 & $0.82-----1.92$ \\
\hline $\begin{array}{l}\text { Quantity of patients } \\
\quad>10 \text { patients } \\
\leq 10 \text { patients }\end{array}$ & $\begin{array}{l}23 \\
12\end{array}$ & $\begin{array}{l}65.7 \\
46.2\end{array}$ & 1.42 & 0.88------2.30 \\
\hline $\begin{array}{l}\text { Income }{ }^{* * *} \\
\quad \leq 3,000.00 \\
3,001 \text { to } 20,000.00\end{array}$ & $\begin{array}{l}29 \\
05\end{array}$ & $\begin{array}{l}60.4 \\
38.5\end{array}$ & 1.57 & 0.76------3.24 \\
\hline
\end{tabular}

Note: ICU - Intensive Care Unit; *Valid responses, excluding those ignored; **Weekly; ***Activities that generate income.

BS prevalence was found to be higher among nurses who terminated employment in the public sector, $66.7 \%(P R=1.28)$, with a weekly workload of 24 hours at night or less, $65.0 \%$ (PR 
$=1.39)$, with a weekly working day equal to or greater than 36 hours, $61.5 \%(P R=1.07)$, who reported not presenting another job, 65.8\% (PR = 1.51), who had the title of specialist in intensive care, 58.9\% (PR $=2.36)$, who reported assisting 10 or more patients, 65.7\% (PR = 1.42), who worked in an adult ICU 66.7\% (PR $=1.25)$ and who reported monthly income equal to or less than $R \$ 3,000.00$ (reais $(R \$)$ is Brazil's currency), $60.4 \%$ ( $P R=1.57)$. The results found did not present statistical significance (Table 4).

BS prevalence showed differences according to the DemandControl Model quadrants. The results showed that intensive care nurses who reported active work (high demand and high control) and high-strain job (high demand and low control) had a prevalence of $72.7 \%$ and $63.9 \%$, respectively. The PR obtained between high and low strain situations was 1.53; however, this result was not statistically significant (Table 5).

Table 5 - Prevalence Ratio and 95\% Confidence Interval for association between Demand-Control Model and Burnout Syndrome groups in intensive care nurses from a large city in Bahia, Brazil, 2016

\begin{tabular}{lcccc}
\hline $\begin{array}{l}\text { Demand-Control Model } \\
\text { group (JCQ) }\end{array}$ & $\mathbf{5}$ & \multicolumn{4}{c}{ Burnout Syndrome } \\
\hline $\begin{array}{l}\text { High strain* } \\
\quad \uparrow \text { Demand }+\downarrow \text { Control }\end{array}$ & 14 & 63.0 & - & - \\
$\begin{array}{l}\text { Low strain } \\
\uparrow \text { Demand }+\downarrow \text { Control }\end{array}$ & 5 & 41.7 & 1.53 & $0.73-3.20$ \\
$\begin{array}{l}\text { Passive work } \\
\uparrow \text { Demand }+\downarrow \text { Control }\end{array}$ & 6 & 42.9 & 1.49 & $0.75-2.93$ \\
$\begin{array}{c}\text { Active work } \\
\uparrow \text { Demand }+\downarrow \text { Control }\end{array}$ & 8 & 72.7 & 0.88 & $0.54-1.41$ \\
\hline
\end{tabular}

Note: $n$ - valid responses; PR - Prevalence Ratio; $95 \% \mathrm{Cl}$ - 95\% Confidence Interval; *PR was calculated with the situation of high strain in the numerator.

\section{DISCUSSION}

The results of this study revealed a high BS prevalence, 53.6\%, a worrying result. The professionals studied work in direct assistance to critically ill patients, in which the error in the execution of procedures can represent serious sequel or even the death of patients. Findings from other studies that used the criterion of Grunfeld et al. (2000) ${ }^{(10)}$ presented results similar to those found in this research, namely: Zanatta and Lucca (2015) (14) found a BS prevalence of $50.8 \%$ in nurses at a hospital specialized in child oncology and hematology in São Paulo. Ribeiro and collaborators (2014) $)^{(15)}$ observed BS prevalence of 55.4\% among nurses working in medical clinics in the state of São Paulo. In another study with health professionals that included nursing workers, Silva, et al. $(2015)^{(12)}$, observed a BS prevalence of $55.3 \%$.

Ntantana and collaborators (2017) ${ }^{(16)}$, in a study carried out in Greece, estimated a BS prevalence of $56.9 \%$ in health workers who worked at ICU and AI-Dardas and collaborators (2010) $)^{(17)}$. In a study carried out in Saudi Arabia, a BS prevalence of $28.9 \%$ was observed among nurses, with a frequency of $45 \%$ of the high level in the emotional exhaustion dimension and $28.9 \%$ in the depersonalization dimension.

In a survey of nurses working at a large university hospital's ICU in the city of São Paulo, SP, Brazil, BS prevalence was $14.3 \%{ }^{(18)}$, identified by the high level, in at least one of the dimensions.
Likewise, in studies conducted in China, Italy and Portugal, they found a burnout prevalence of $16.0 \%^{(19)}, 35.7 \%^{(20)}$ and $31.0 \%^{(21)}$, respectively. Most of results of the consulted studies revealed high estimates of BS prevalence among intensive care nurses from different countries.

This study observed a higher frequency of the high level in the dimension emotional exhaustion (41.0\%), followed by low personal fulfillment/inefficiency (17.0\%) and depersonalization (6.5\%). In other studies with nurses, rates were found that ranged from $16.1 \%$ to $42.6 \%$ for emotional exhaustion, from $6.1 \%$ to $35.6 \%$ for personal fulfillment and $2.4 \%$ to $25 \%$ for depersonalization ${ }^{(21-24)}$.

In a study conducted by Zhang, Huang, Guan (2014) with intensive care nurses in China, a frequency of $43.2 \%$ was observed in the emotional exhaustion dimension, followed by $41.2 \%$ in the personal fulfillment dimension and $26,1 \%$ in depersonalization. Thus, the results point to a higher frequency of the high level in the emotional exhaustion dimension among nurses working at ICU.

Concerning the nurses' profile, according to sociodemographic characteristics and life habits, it is a young population, predominantly female, with a partner and without children, supporting Muse's, Love's, Christensen's findings (2015) ${ }^{(24)}$. In this study, a higher BS prevalence was found among younger individuals in the emotional exhaustion dimension. Other studies with nurses in ICU and in critical units observed a higher prevalence of burnout among younger individuals than those with more advanced age, showing that this population can be considered more exposed to stressful situations, which may be related to the low experience in dealing with critical situations that require quick responses in the workplace ${ }^{(18,24)}$.

Regarding life habits, most reported performing physical activity, not smoking and using alcohol. In this study, an association was observed between physical activity and low burnout prevalence. The consulted literature points to the benefits of physical activity in workers' health, such as cognitive improvement, reduction of stress, symptoms of anxiety and depression, reduction of conflicts in interpersonal relationships and less tired feeling during work activities ${ }^{(25)}$.

The results showed an association between alcohol consumption (alcoholism) and BS. Although it is not possible to qualify these professionals as problem drinkers, the American Nurses Association (2008) estimated that about $10 \%$ of nurses are dependent on alcohol and other drugs, which can compromise their health and professional performance, putting safety at risk of patients ${ }^{(26)}$.

Concerning the nurses' profile, according to the job variables, the average time of work at ICU was approximately 6 years, similar to that found in another study with these professionals ${ }^{(21)}$. There was a high workload in other paid activities in the nursing field. Most have a specialization degree in intensive care and declared to receive a monthly income between $R \$ 3,000.00$ and $R \$ 6,000.00$.

The authors corroborate that imbalance between salary and workload can significantly increase the probability that nurses will have $\mathrm{BS}^{(21)}$. The category of nursing, even today, struggles to define a minimum salary. Most nurses reported working elsewhere, this fact may be related to a search for increased income. In a study by Zanatta and Lucca $(2015)^{(14)}$, it was observed that 
$35.1 \%$ of nurses had two employment relationships, which can contribute to work overload ${ }^{(14,27-28)}$.

Most workers studied showed that they assisted more than 10 patients per shift and BS prevalence was higher than those who reported assisting less than 10 patients per shift. ANVISA Board Resolution (RDC) 26, published on May 11, 2012, defines that nurses assisting in ICU must assist, at most, ten patients (1:10) (29). Considering that nurse-patient relationship can be associated with quality care with safety and efficiency, corroborates Resolution COFEN 543/2017 ${ }^{(30)}$, which considers the quantitative and qualitative of nursing professionals to directly interfere with patient care safety and quality ${ }^{(31)}$.

The authors corroborate that patient safety influences the improvement of quality in health services and is related to good care practices ${ }^{(32)}$. The concern for patient safety aims to reduce the risk of harm associated with the care provided by health workers to an acceptable minimum ${ }^{(33)}$. It is important to highlight that ICU is a sector that serves people in serious condition who need immediate care and in adequate conditions. Thus, the overload of demands in the ICU environment and BS occurrence among nursing workers can impair the quality of care provided, putting patients' safety at risk ${ }^{(34)}$.

BS prevalence was high in all Demand-Control Model quadrants. The intensivist nurses studied had a higher BS prevalence than that found in other studies ${ }^{(13,20-21)}$. There was a high BS prevalence in high strain situation, confirming the main prediction of the model, that work in high strain (high demand and low control) presents a greater risk to workers' mental health. High BS prevalence in active work situation (high demand and high control) was an unexpected finding, considering that, in most studies, a higher prevalence is observed in the passive work situation. These findings suggest that, although professionals consider that their work has high control, high demand seems to be more associated with mental distress. This result corroborates that obtained by Tironi and collaborators $(2009)^{(5)}$, who found a high BS prevalence in high strain situation, confirming demand as the most important component for mental distress in intensive care workers.

\section{Study limitations}

It is important to highlight some limitations of the cross-sectional study, such as the evaluation of the relationship between exposure and outcome at the same time, which provides only a picture of the situation, making it impossible to establish a causal link. It is also important to consider the effect of healthy workers on the prevalence found. In these studies, healthy workers are selected, excluding sick workers who are away from work. Moreover, as this is an exploratory study, interaction and confounding analyzes were not carried out, procedures that allow establishing more robust evidence. Finally, in studies that use self-administered questionnaires, even though they are validated and widely used in research, they have difficulties in controlling data losses.

\section{Contributions to nursing}

Studies on BS prevalence in intensive care nurses are still scarce. Although it is a population that has specific characteristics, the findings revealed a high BS prevalence, which encourages further investigations, which can more precisely identify the factors associated with this prevalence in Intensive Care Units.

\section{CONCLUSION}

The results revealed a high BS prevalence and a high workload among intensive care nurses. An association was observed between BS and age equal to or below 34 years, tobacco consumption, use of alcoholic beverages, night shift hours equal to or less than 24 hours, not having another job, having a title of specialist in Therapy Intensive, assisting 10 or more patients per shift, perceiving monthly income equal to or less than $\mathrm{R} \$ 3,000.00$ and considering active or high-strain job.

The results of this study can contribute to a discussion about working conditions in the ICU environment that exposes nursing workers to stressful factors, especially when caring for patients in critical situations and at risk of death.

\section{ERRATUM}

Article "Burnout Syndrome and Associated Factors in Intensive Care Unit Nurses", with number of DOI: https:// doi.org/10.1590/0034-7167-2019-0535, published in the journal Revista Brasileira de Enfermagem, 74(Suppl 3):e20190535, on the first page:

Where to read:

Davi Félix Martins Júnior'

ORCID: 0000-0002-7686-7373

Read:

Davi Félix Martins Júnior'

ORCID: 0000-0002-7687-7373

\section{REFERENCES}

1. Tironi MOS, Nascimento Sobrinho CL, Barros DS, Reis EJFB, Marques Filho ES, Almeida A, et al. Professional Burnout Syndrome among Intensive Care Physicians in Salvador, Brazil. Rev Assoc Med Bras. 2009;55(6):656-62. doi: 10.1590/S0104-42302009000600009

2. Maslach C, Schaufeli WB, Leiter MP. Job burnout. Ann Rev Psychol. 2001;52(1):397-422. doi: 10.1146/annurev.psych.52.1.397 
3. Colville GA, Dawson D, Rabinthiran S, Chaudry-Daley Z, Perkins-Porras L. A survey of moral distress in staff working in intensive care in the UK. J Intensive Care Soc. 2019;20(3):196-203. doi: 10.1177/1751143718787753

4. Mudallal RH, Othman WMAL, Hassan NF. Nurses' Burnout: the influence of leader empowering behaviors, work conditions, and demographic traits. J Health Care Org Provis Financ. 2017;54: 1-10. doi: 10.1177/0046958017724944

5. Barros DS, Tironi MOS, Nascimento Sobrinho CL, Neves FS, Bitencourt AGV, Almeida AM, et al. Intensive care unit physicians: sociodemographic profile, working conditions and factors associated to the burnout syndrome. Rev Bras Ter Intensiva. 2008;20(3):235-40. doi: 10.1590/ S0103-507X2008000300005

6. Ministério da Saúde (BR). Diretrizes e Normas Regulamentadoras de Pesquisas Envolvendo Seres Humanos: Conselho Nacional de Saúde [Internet]. 2012 [cited 2019 Nov 20]. Available from: https://bvsms.saude.gov.br/bvs/saudelegis/cns/2013/res0466_12_12_2012.html

7. Karasek RA. Job Content Questionnaire and user`s guide. Revision 1.1. Lowell: University of Massachusetts; 1985.

8. Maslach C, Jackson S. The measurement of experience Burnout. J Occupation Behav. 1981;2:99-113.

9. Maslach C, Goldberg J. Prevention of Burnout: news perspectives. Appl Prev Psychol. [Internet]. 1998[cited 2019 Nov 20];7(1):63-74. Available from: https://www.researchgate.net/publication/222495735_Prevention_of_burnout_New_perspectives.

10. Grunfeld E, Whelan, TJ, Zitzelsberger L, Willan AR, Montesanto B, Evans WK. Cancer care workers in Ontario: prevalence of burnout, job stress and job satisfaction. CMAJ [Internet]. 2000[cited 2019 Nov 20];163:166-9. Available from: https://pubmed.ncbi.nlm.nih.gov/10934978/

11. Moore, DS. A estatística básica e sua prática. Rio de Janeiro: LTC Editora, 2017.

12. Silva JLL, Soares RS, Costa FS, Ramos DS, Lima FB, Teixeira LR. Psychosocial factors and prevalence of burnout syndrome among nursing workers in intensive care units. Rev Bras Ter Intensiva. 2015;27(2):125-33. doi: 10.5935/0103-507X.20150023

13. Araújo ST, Silva SH, Silva MN, Coelho ACC, Pires CGS, Melo CMM. Job insecurity among nurses, nursing technicians and nursing aides in public hospitals. Rev Esc Enferm USP. 2018;52:03411. doi: 10.1590/s1980-220x2017050503411

14. Zanatta AB, Lucca SR. Prevalence of Burnout syndrome in health professionals of an onco-hematological pediatric hospital. Rev Esc Enferm USP [Internet]. 2015[cited 2019 Nov 20];49(2):251-8. Available from: http://www.revistas.usp.br/reeusp/article/view/103194/101597.

15. Ribeiro VF, Filho CF, Valenti VE, Ferreira M, Abreu LC, de Carvalho TD, Ferreira C. Prevalence of burnout syndrome in clinical nurses at a hospital of excellence. Int Arch Med. 2014;7:22. doi: 10.1186/1755-7682-7-22

16. Ntantanaa A, Matamisa D, Savvidoua S, Giannakoub M, Gouvac M, Nakosd G, Koulourasd V. Burnout and job satisfaction of intensive care personnel and the relationship with personality and religious traits: an observational, multicenter, cross-sectional study. Intensive Crit Care Nurs. 2017. doi: 10.1016/j.iccn.2017.02.009

17. Al-Dardas H, Al-Enizi N, Al-Gazal M, Al-Maghrabi G, Al-Turki H, Al-Turki R. Burnout syndrome among multinational nurses working in Saudi Arabia. Ann Afr Med. 2010;9(4):226-9. doi: 10.4103/1596-3519.70960

18. Vasconcelos EM, Martino MMF, França SPS. Burnout and depressive symptoms in intensive care nurses: relationship analysis. Rev Bras Enferm. 2018;71(1):135-41. doi: 10.1590/0034-7167-2016-0019

19. Zhang XC, Huang DS, Guan P. Job burnout among critical care nurses from 14 adult intensive care units in northeastern China: a crosssectional survey. BMJ Open 2014;4:e 004813. doi: 10.1136/bmjopen-2014-004813

20. Giannini A, Miccinesi GE, Buzzoni C, Borreani C. Partial liberalization of visiting policies and ICU staff: a before-and-after study. Intensive Care Med. 2013;39:2180-7. doi: 10.1007/s00134-013-3087-5

21. Teixeira C, Ribeiro O, Fonseca AM, Carvalho AS. Burnout in intensive care units - a consideration of the possible prevalence and frequency of new risk factors: a descriptive correlational multicentre study. BMC Anesthesiol. 2013, 13:38. doi: 10.1186/1471-2253-13-38

22. Benitez M, Rodriguez E. Burnout's Syndrome in the nursing staff of intensive care in a hospital of Montevideo city. Enferm (Montev.) [Internet]. 2014[cited 2019 Nov 20];3(1):21-7. Available from: http://ucu.edu.uy/sites/default/files/publicaciones/2014/revista_enfermeria_cuidados_ humanizados_vol.3.1_jun2014.pdf

23. Afecto MCP, Teixeira MB. Evaluation of occupational stress and burnout syndrome in nurses of an intensive care unit: a qualitative study. Online Braz J Nurs [Internet]. 2009 [cited 2019 Nov 20];8(1). Available from: http://www.objnursing.uff.br/index.php/nursing/rt/printerFriendly /j.1676-4285.2009.2107/453

24. Muse S, Love M, Christensen K. Intensive Out Patient therapy for Clergy Burnout: how much difference can a week make? J Relig Health. 2015;55(1):147-58. doi: 10.1007/s10943-015-0013-x

25. Silva RS, Silva I, Silva RA, Souza L, Tomasi E. Atividade física e qualidade de vida. Ciênc Saúde Coletiva. 2010; 15(1):115-120.

26. American Nurses Association (ANA). Nursing quality indicators: definitions and implications [Internet]. 2008[cited 2019 Nov 20]. Available from: http://www.nursingworld.org/

27. Galindo RH, Feliciano KVO, Lima RAS, Souza Al. Burnout Syndrome among General Hospital Nurses in Recife. Rev Esc Enferm USP. 2012;46(2):420-7. doi: 10.1590/S0080-62342012000200021

28. Lorenz VR, Benatti MCC, Sabino MO. Burnout and Stress Among Nurses in a University Tertiary Hospital. Rev Latino-Am Enfermagem. 2010;18(6):1084-91. doi: 10.1590/S0104-11692010000600007

29. Agência Nacional de Vigilância Sanitária - ANVISA. Resolução № 26 de 11 de maio de 2012 [Internet]. Ministério da Saúde; 2012 [cited 2019 Nov 20]. Available from: http://bvsms.saude.gov.br/bvs/saudelegis/anvisa/2012/rdc0026_11_05_2012.html 
30. Conselho Federal de Enfermagem. Resolução 543/2017. In: Conselho Federal de Enfermagem [Internet]. Brasília, DF: 2017[cited 2019 Nov 20]. Available from: http://www.cofen.gov.br/resolucao-cofen-no-05272016_46348.html

31. Rodrigues CCFM, Santos VEP, Sousa P. Patient safety and nursing: interface with stress and Burnout Syndrome. Rev Bras Enferm. 2017;70(5):1083-8. doi: 10.1590/0034-7167-2016-0194

32. Sousa P, Mendes W. Segurança do paciente: conhecendo os riscos nas organizações de saúde. Rio de Janeiro: EAD/ENSP; 2014.

33. Guirardello EB. Impact of critical care environment on burnout, perceived quality of care and safety attitude of the nursing team. Rev Latino-Am Enfermagem. 2017;25:e2884. doi: 10.1590/1518-8345.1472.2884

34. Novaretti MCZ, Santos EV, Quitério LM, Daud-Gallotti RM. Sobrecarga de trabalho da enfermagem e incidentes e eventos adversos em pacientes internados em UTI. Rev Bras Enferm. 2014;67(5):692-9. doi: 10.1590/0034-7167.2014670504 